\title{
PRODUKSI BRIKET DAN KOMPOS DARI LIMBAH CANGKANG DAN TANDAN KOSONG KELAPA SAWIT DI DESA GIRI MULYA BENGKULU UTARA
}

\section{PRODUCTION OF BRICKETS AND ORGANIC FERTILIZERS FROM SHELLS AND OIL PALM EMPTY FRUIT BUNCHES IN THE VILLAGE OF GIRI MULYA NORTH BENGKULU}

\author{
Oleh: \\ *Devi Ratnawati, Morina Adfa, Eni Widiyati \\ Chemistry Department, University of Bengkulu, Bengkulu, Indonesia \\ *Email:devi_r64@yahoo.com
}

\begin{abstract}
The purpose of the program IbM are: (a) training waste processing of palm oil and corn as an energy (b) accompanying ways of processing and manufacturing of palm oil waste products on home industry. The implementation of the program includes improvement of knowledge and skills, demonstrations and coaching as well as technology training science applied sewage treatment production of palm oil for processing into brickets and organic fertilizers which high economic value. From some of the activities that have been done, the community was very enthusiastic in participating in these activities, especially on processing palm oil empty fruit bunches and shells into briquettes and organic fertilizers.
\end{abstract}

Keywords: palm oil waste, brickets, empty fruit bunches

\section{PENDAHULUAN}

Desa Giri Mulya Kabupaten Bengkulu Utara berjarak sekitar 105 KM dan 95 KM dari ibu kota Provinsi Bengkulu. Daerah ini dikenal sebagai salah satu daerah penghasil kelapa sawit dan jagung terbesar di Bengkulu Utara, sebanyak luas lahan perkebunan mencapai 309,1 Ha (BPS, 2014). Setiap tahunnya dihasilkan 84.872 ton sawit dan 26.332 ton dengan 67.000 ton/tahun limbah bahan organik perkebunan berupa tandan kosong kelapa sawit (TKKS), cangkang, dan tandan sawit (Pecawan, 2015).

Lokasi Desa Giri Mulya yang ada di kabupaten Bengkulu Utara terletak di daerah pedalaman sehingga kegiatan Pengabdian Pada Masyarakat (P2M) di bidang IPTEKS terapan yang dilakukan oleh Universitas Bengkulu ataupun Perguruan Tinggi lainnya sangat jarang sampai ke wilayah-wilayah tersebut. Hal ini mengakibatkan masyarakat jarang terlibat dalam kegiatan-kegiatan ilmiah yang dilakukan oleh Perguruan Tinggi, sebagai dampaknya pengetahuan dan pemahaman para masyarakat di wilayah ini masih kurang terkait dengan pengolahan limbah organik sebagai energi alternatif dan kegiatan IPTEKS lainnya.

Jauhnya jarak desa ini dari kota disekitarnya dan kondisi jalan yang buruk menyebabkan pemenuhan kebutuhan masyarakat terkendala oleh jarak dan transportasi. Selama ini kebutuhan masyarakat kabupaten tersebut dipasok dari Kota Bengkulu menggunakan jalur darat, dikarenakan jarak tempuh yang jauh dan kondisi jalan yang buruk menyebabkan harga jual kebutuhan menjadi sangat mahal. Diantara kebutuhan yang 
sangat penting adalah bahan bakar gas dan pupuk subsidi, tidak adanya jalan alternatif mengakibatkan pasokan dikirim melalui jalur darat sehingga dengan kondisi jalan yang sangat buruk membuat harga melonjak lebih dari $20 \%$ dari harga normal.

Dengan adanya penghapusan subsidi untuk BBM dan pupuk, membuat kehidupan masyarakat di daerah ini menjadi semakin sulit. Bahan bakar gas untuk keperluan rumah tangga sulit didapat, apalagi setelah pengapusan subsidi untuk bahan bakar gas. Harga buah sawit yang merosot tajam selama 3 tahun terakhir membuat kehidupan masyarakatnya menjadi semakin sulit. Banyak warga yang beralih menggunakan kayu bakar untuk memasak dengan memanfaatkan pelepah sawit ataupun Tandan Kosong Kelapa Sawit (TKKS) dan cangkang sisa penggilingan sawit yang dibuang berserakan oleh pabrik pengolahan kelapa sawit PT. Sandabi Indah Lestari yang terdapat di daerah tersebut. Dikarenakan jumlahnya sangat banyak dan semakin menumpuk, maka menjadi limbah yang menimbukan bau sangat tidak sedap dan mengganggu keindahan lingkungan. Setelah limbah organik ditumpuk lebih dari 1 bulan maka akan timbul bau tidak sedap akibat produksi gas metana $\left(\mathrm{CH}_{4}\right)$ dan $\mathrm{CO}_{2}$, gas ini dapat digunakan sebagai alternatif bahan bakar gas, namun jika terlepas ke udara dapat menyebabkan peningkatan efek rumah kaca.

Penghentian subsidi pupuk juga berdampak buruk bagi daerah ini, sejak diberlakukan kebijakan tersebut maka saat ini daerah tersebut kekurangan 15 ribu ton pupuk setiap tahunnya untuk memenuhi kebutuhan lahan perkebunan mereka yang sangat luas (Pecawan, 2015). Hanya 30\% jumlah pupuk yang dipenuhi oleh pemerintah, sisanya mereka mengambil dari provinsi lain dengan harga yang tinggi. Walaupun daerah ini terbilang makmur, tetapi kabupaten ini termasuk dalam kategori daerah tertinggal ditinjau dari fasilitas yang dimiliki daerah, keterbaruan teknologi, sumber daya manusia dan penghasilan rata-rata masyarakatnya. Image atau pandangan bahwa daerah ini adalah daerah makmur karena terdapat 1 perusahaan swasta besar tidak sepenuhnya benar, karena roda ekonomi dipegang oleh orang tertentu dengan modal besar dan perkebunannya yang sangat luas. Hal ini ditunjukkan lebih dari $20 \%$ masyarakatnya masih dikategorikan miskin.

Akar masalah sebenarnya yang mereka hadapi adalah minimnya pengetahuan dan ketrampilan untuk mengolah limbah organik perkebunan mereka berikut hasil sampingnya yang berjumlah sangat fantastis, menjadi sumber energi alternatif untuk mengatasi kelangkaan bahan bakar gas akibat pencabutan subsidi. Masalah selanjutnya adalah para petani di desa tersebut belum bisa mengolah limbah hasil perkebunan mereka menjadi pupuk organik bernutrisi tinggi sehingga masih mengadalkan asupan pupuk dari pemerintah. Selain itu, karena keterbatasan sumber daya manusia maka para petani belum dapat mengolah hasil samping perkebunan mereka menjadi barang kerajinan yang bernilai ekonomis tinggi sehingga dapat menambah penghasilan rumah tangganya. Beberapa kali para kelompok tani berinisiatif untuk mencari narasumber yang kompeten untuk membantu memecahkan permasalahan mereka, namun karena keterbatasan kemampuan maka sampai saat ini belum tercapai keinginan tersebut.

Bertolak dari tersedianya limbah bahan organik berupa Tandan kosong kelapa sawit (TKKS) berikut cangkangnya dengan jumlah yang sangat melimpah maka Tim IbM FMIPA Universitas Bengkulu mencoba untuk membantu meningkatkan pengetahuan dan ketrampilan kepada para warga kelompok tani untuk mengolah limbah bahan organik yang dihasilkannya menggunakan teknologi fermentasi. Adapun akan dilakukan pelatihan produksi biogas sederhana skala rumah tangga dengan bahan dasar limbah organik perkebunan. Kemudian pelatihan pengolahan limbah produksi biogas berupa slurge yang 
dapat dimanfaatkan sebagai pupuk organik nutrisi tinggi dan pengolahan limbah organik lainnya menjadi kerajinan tangan dengan nilai ekonomis tinggi. Kegiatan ini dilakukan dengan harapan daerah ini dapat menjadi daerah mandiri dalam pemenuhan kebutuhan energi dan lahan pertaniannya saat ini dan berlanjut di masa yang akan datang sehingga mengurangi kebergantungan beban energi dan bantuan pemerintah.

Permasalahan selanjutnya adalah, para petani dan warga sekitar belum mampu mengolah limbah sampah organik menjadi sumber energi alternatif selain minyak bumi dan pengolahan hasil sampingnya, sehingga mereka masih mengandalkan energi fosil sebagai sumber energi utama dan bergantung pada pasokan pupuk subsidi pemerintah untuk pemenuhan kebutuhan perkebunan mereka walaupun dengan harga yang sangat mahal. Dengan sedikit implementasi IPTEKS terapan maka kelangkaan bahan bakar gas dan pupuk subsidi di daerah ini dapat teratasi dengan memanfaatkan limbah organik yang mereka hasilkan dari perkebunan mereka sendiri.

\section{METODE PENGABDIAN}

Metode kegiatan pengabdian ini diberikan dalam bentuk penyuluhan dan praktek, adapun beberapa kegiatan tersebut adalah:

\section{a.) Pembuatan briket arang cangkang kelapa sawit}

Bahan berupa limbah cangkang sawit dimasukkan dalam tungku pembakaran (kompor khusus) selama lebih dari 1 jam hingga material menjadi arang. Proses ini dilakukan sembari menggunakan arang untuk memasak makanan menggantikan bahan bakar gas. Arang dikeluarkan dan biarkan beberapa saat agar panas mereda, kemudian ditumbuk hingga halus dan diayak. Panaskan tepung tapioka hingga menjadi bubur lem, campurkan arang halus dengan bubur lem tepung tapioka dengan perbandingan ideal $1 \mathrm{~kg}$ bubur tapioka dengan $10 \mathrm{~kg}$ arang halus. Adukan dimasukkan ke dalam cetakan paralon, briket basah dikeringkan dengan menjemurnya di bawah sinar matahari. Setelah kering briket disimpan dan siap untuk digunakan (Hendra dan Winarni, 2003).

\section{b.) Pembuatan pupuk organik berbahan dasar tandan kosong kelapa sawit (TKKS)}

TKKS diambil dari pabrik dalam keadaan masih basah disusun 1 lapis dengan posisi mendatar, kemudian di taburi dengan starter biokompos beserta dedak. Hal ini dilakukan berulang kali sampai diperoleh tumpukan material TKKS. Pada bagian tengah diberi pipa paralon 3 inch $\pm 0,5$ meter sebagai lubang udara pembuangan gas. Kemudian tutup seluruh permukaan tumpukan TKKS dengan plastik/terpal berwarna gelap. Selama proses akan terjadi pengeluaran gas yang sangat banyak, hal ini menimbulkan polusi bau karena fermentasi TKKS menimbulkan bau yang sangat menyengat. Selama kurang lebih 2-3 bulan maka kompos siap digunakan (Hasibuan, 2012).

\section{HASIL DAN PEMBAHASAN}

Kegiatan pengabdian masyarakat telah dilakukan di Desa Giri Mulya yang meliputi kegitan pembuatan briket arang cangkang kelapa sawit dan pupuk kompos dari tandan kosong kelapa sawit.

1.) Pemanfaatan cangkang sawit sebagai bahan bakar memasak

Jika kita mengunjungi pabrik pengolahan sawit maka akan mudah dijumpai bertonton gundukan cangkang sawit di sekitar areal pabrik kelapa sawit. Walau sudah menjadi limbah bukan berarti akan dibuang begitu saja. Beberapa perusahaan akan memanfaatkan limbah cangkang sawit sebagai bahan bakar pada tungku boiler. Boiler sendiri merupakan 
bagian terpenting pada pabrik pengolahan kelapa sawit. Selain digunakan untuk proses 'perebusan' kelapa sawit, boiler juga menghasilkan uap panas (steam) yang akan dikonversi menjadi energi penggerak turbin-turbin. Termasuk turbin penggerak untuk menghasilkan energi listrik. Makanya pabrik-pabrik yang berada jauh di pedalaman tetap mempunyai pasokan listrik yang bersumber dari boiler tadi (Abidin, 2015).

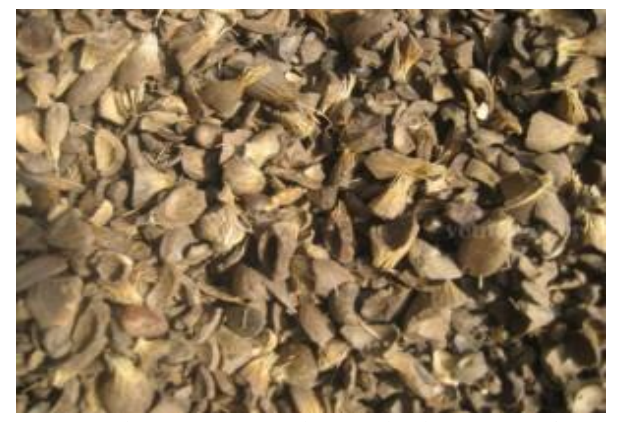

Gambar 1. Cangkang kelapa sawit

Kebutuhan cangkang sawit sebagai bahan bakar pada PKS sendiri biasanya surplus. Maka kelebihan cangkang ini akan dijual. Saat ini harga cangkang sawit dipasaran berkisar antara Rp.300,- sampai Rp.500,- /kg (bukan harga yang dijual langsung oleh PKS). Besarnya harga cangkang juga ditentukan oleh kualitas (basah/kering) dan jarak lokasi cangkang sawit itu berasal. Bagaimanapun harga cangkang sawit Jauh lebih murah dibanding harga gas saat ini, bahkan jauh lebih murah juga bila dibandingkan dengan batubara misalnya. Berikut ini adalah alasan mengapa kita seharusnya dapat memanfaatkan cangkang sawit untuk dimanfaatkan dalam kehidupan sehari-hari.

- Ketersediaan cangkang sawit sangat besar dan sangat mudah diperoleh di wilayah pabrik.

- Dapat mengurangi limbah produksi pabrik kelapa sawit, karena cangkang sawit merupakan salah satu dari limbah atau hasil sampingan dari produksi tersebut.

- Nilai kalor dari cangkang sawit memenuhi persyaratan untuk mampu mencukupi kebutuhan panas yang diperlukan.

- Sisa dari pembakaran cangkang sawit kemudian dapat dimanfaatkan lagi sebagai pupuk untuk tanaman kelapa sawit atau pun diolah lagi menjadi briket cangkang kelapa sawit.

- Harga cangkang sawit jauh lebih ekonomis dibanding bahan bakar lainnya seperti batu bara.
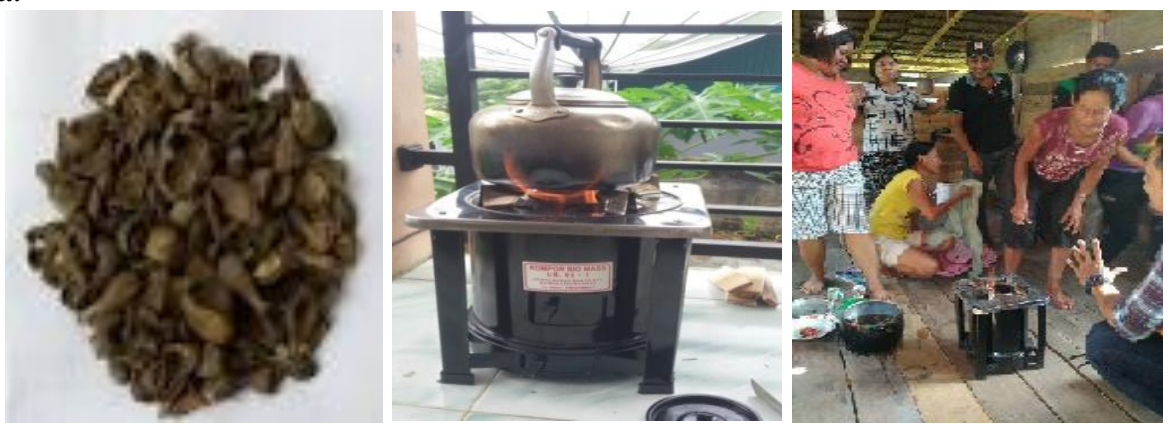

Gambar 2. Pemanfaatan cangkang sawit sebagai bahan bakar memasak 
2.) Pembuatan briket dari arang cangkang kelapa sawit

Pada kelapa sawit, cangkang merupakan lapisan pelindung daging buah yang bertekstur keras. Sekilas arang sawit ini terlihat mirip sekali dengan arang batok kelapa. Bedanya terdapat pada kabar abu yang dihasilkan sebab mempengaruhi kualitas produk arang tersebut. Cangkang kelapa sawit sangat bagus diolah menjadi arang karena mengandung karbon berkadar tinggi dan berat jenis mencapai 1,4 g/ml sehingga mampu menghasilkan energi panas maksimal hingga $20.093 \mathrm{~kJ} / \mathrm{Kg}$.

Briket arang dibuat dengan membakar cangkang kelapa sawit memakai sistem karbonasi. Kelebihan dari briket ini antara lain bisa dibuat terus-menerus, tidak mengandung sulfur, tidak mencemari udara, dan tidak mengeluarkan emisi gas beracun seperti NOx dan SOx. Pemanfaatan cangkang kelapa sawit menjadi arang juga dapat meningkatkan efisiensi pemakaian limbah perkebunan.

Pembuatan briket arang kelapa sawit dapat melalui 2 metode, yang pertama cangkang dibakar secara manual kemudian ditumbuk dan dicetak. Kemudian yang paling ekonomis adalah menggunakan cangkang arang kelapa sawit untuk memasak dan arang sisa memasak ditumbuk dan dicetak kembali menjadi briket.

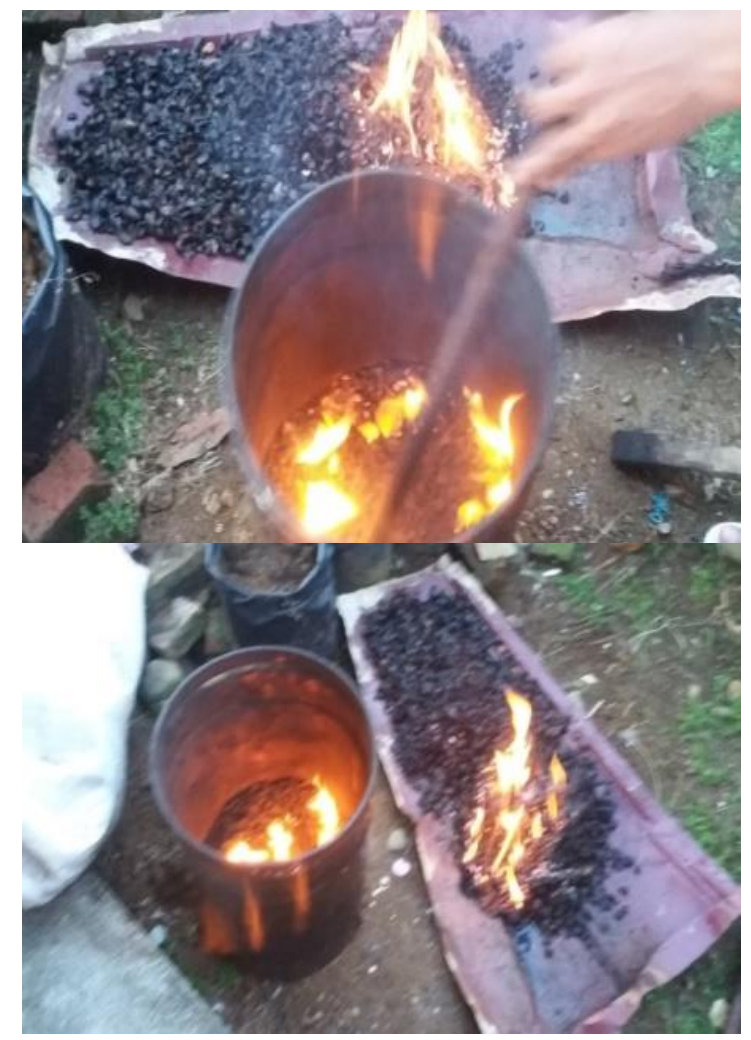

Gambar 3. Kegiatan pembuatan pembakaran cangkang untuk briket 

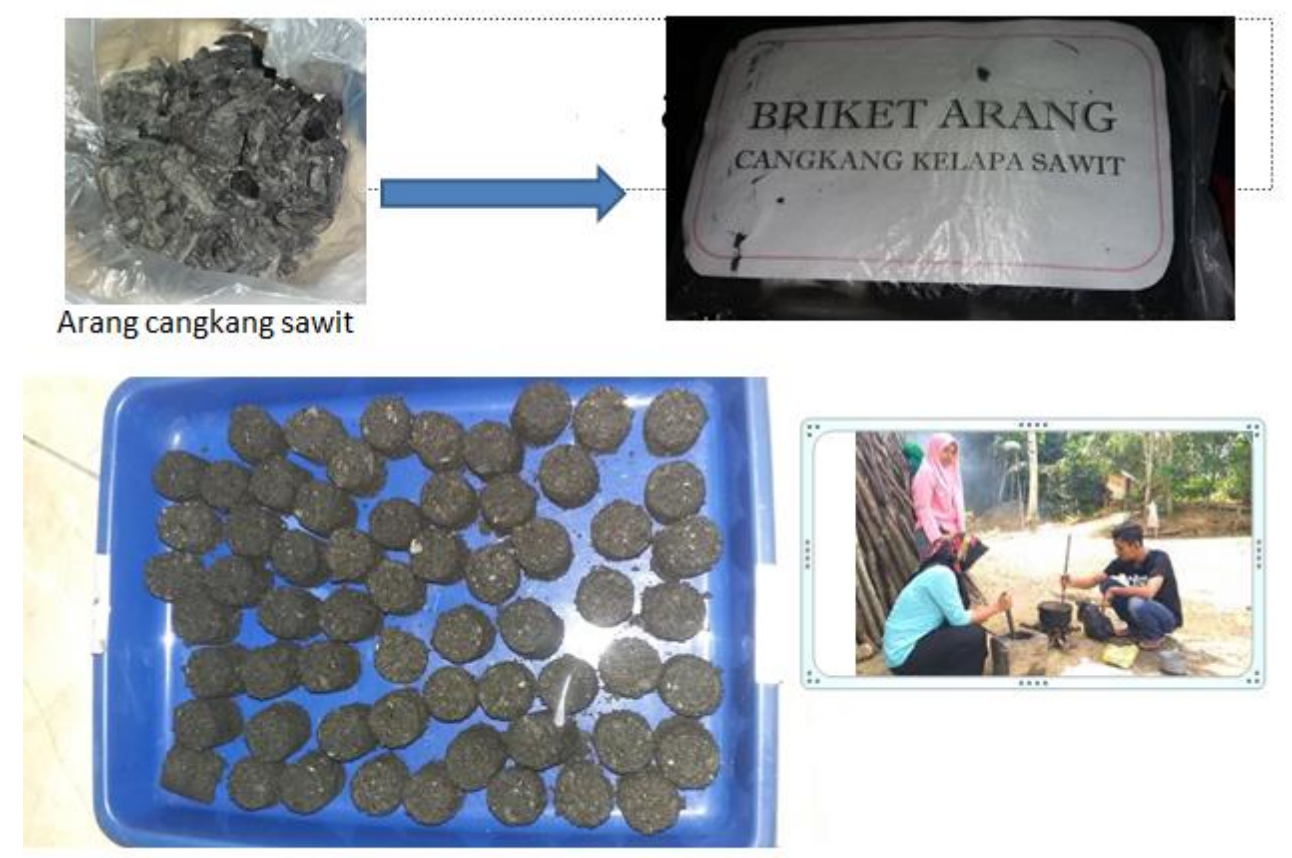

Gambar 4. Skema pembuatan briket dari arang cangkang kelapa sawit

\section{3.) Pembuatan kompos dari Tandan Kosong Kelapa Sawit (TKKS)}

Pupuk kompos adalah salah satu pupuk organik buatan manusia yang dibuat dari proses pembusukan sisa-sisa bahan organik seperti tanaman maupun hewan. Proses pengomposan dapat berlangsung secara aerobik yaitu melibatkan oksigen dan anaerobik atau tanpa menggunakan osigen di dalam prosesnya. Proses dekomposisi atau penguraian inilah yang menjadikannya disebut sebagai pupuk kompos. Sedangkan arti dari proses pengomposan adalah proses dimana bahan organik mengalami penguraian secara biologis, khususnya oleh mikroba-mikroba yang memanfaatkan bahan organik sebagai sumber energi (Isroi, 2008).

Membuat kompos berarti mengatur dan mengontrol proses alami tersebut agar kompos dapat terbentuk lebih cepat. Proses ini meliputi membuat campuran bahan yang seimbang, pemberian air yang cukup, pengaturan aerasi, dan penambahan aktivator pengomposan. Sebagai pupuk alami, keberadaan kompos terutama sangat dibutuhkan untuk memperbaiki kondisi fisik tanah, disamping untuk menyuplai unsur hara.

Tandan kosong kelapa sawit (TKKS) merupakan salah satu jenis limbah padat yang paling banyak dihasilkan oleh pabrik kelapa sawit. Menurut Darnoko (1992), dari satu ton tandan buah segar (TBS) yang diolah akan dihasilkan minyak sawit kasar (CPO) sebanyak 0,21 ton $(21 \%)$ serta minyak inti sawit (PKO) sebanyak 0,05 ton $(5 \%)$. Sisanya merupakan limbah dalam bentuk tandan buah kosong, serat dan cangkang biji yang jumlahnya masingmasing sekitar 23\%, 13,5\% dan 5,5\% dari tandan buah segar. Tandan kosong kelapa sawit yang merupakan 23 persen dari tandan buah segar, mengandung bahan lignoselulosa sebesar 55-60 persen berat kering. Dengan produksi puncak kelapa sawit per hektar sebesar 20-24 ton tandan buah segar per tahun berarti akan menghasilkan 2,5-3,3 ton bahan lignoselulosa. 
Pengolahan/pemanfaatan TKKS oleh PKS masih sangat terbatas. Sebagian besar pabrik kelapa sawit (PKS) di Indonesia masih membakar TKKS dalam incinerator, meskipun cara ini sudah dilarang oleh pemerintah. Alternatif pengolahan lainnya adalah dengan menimbun (open dumping), dijadikan mulsa di perkebuna kelapa sawit, atau diolah menjadi kompos. Cara terakhir merupakan pilihan yang terbaik, namun cara ini belum banyak dilakukan oleh PKS karena adanya beberapa kendala, yaitu waktu pengomposan, fasilitas yang harus disediakan, dan biaya pengolahan TKKS tersebut. Dengan cara konvensional, dekomposisi TKKS menjadi kompos dapat berlangsung dalam waktu 6 bulan s/d 1 tahun. Lamanya waktu ini berimplikasi pada luas lokasi, tenaga kerja, dan fasilitas yang diperlukan untuk mengomposkan TKKS tersebut.
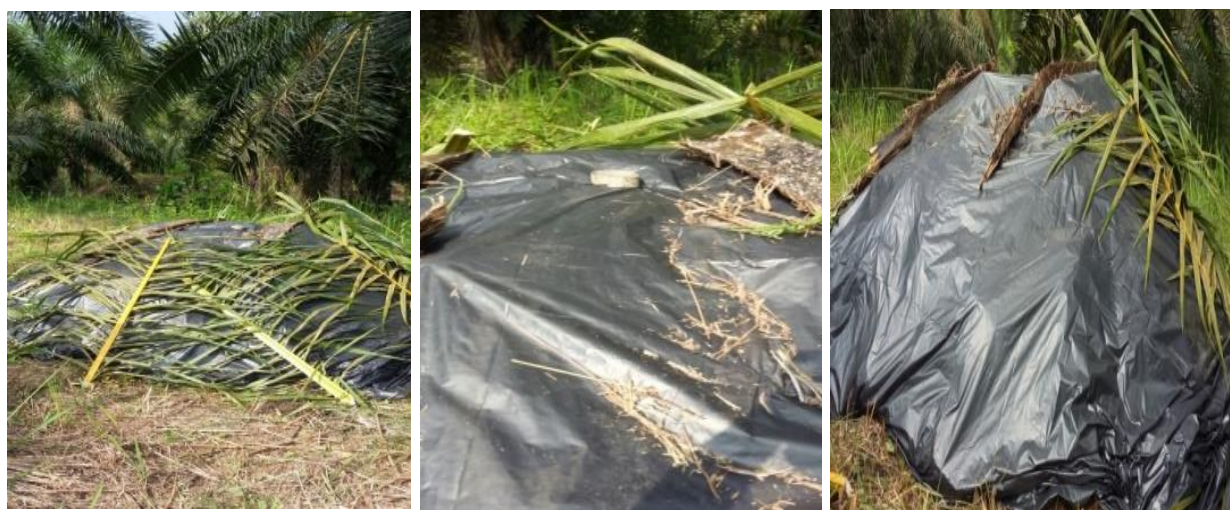

Gambar 5. Pembuatan pupuk kompos

\section{KESIMPULAN DAN SARAN}

\section{Kesimpulan}

Sampai dengan selesainya kegiatan ini, masyarakat sangat senang sekali karena sangat terbantu dalam hal mensubstitusi kebutuhan bahan bakar memasak mereka dengan memanfaatkan cangkang kelapa sawit yang bisa diambil gratis di pabrik dekat rumah mereka.

\section{Saran}

Kelompok tani mesti saling membagi ilmu yang telah didapat dengan kelompok yang lain supaya desa menjadi lebih maju dan bisa menjadi masyarakat yang mandiri.

\section{UCAPAN TERIMA KASIH}

Terimakasih kepada Kemenristek Dikti yang telah membiayai program pengabdian ini melalui PKM 2017.

\section{DAFTAR PUSTAKA}

Abidin, Z, 2015, Cara Pembuatan Briket Dari Arang Kelapa Sawit, http://klpswt.blogspot.co.id/2015/09/cara-pembuatan-arang-dari-cangkang.html.

BPS Muko-Muko, 2014, Luas Panen Dan Produksi Menurut Jenis Komoditas Di Kabupaten Bengkulu Utara. 
Hasibuan, Z.H, Sabrina, Sembiring M.B, 2012, Potensi Bakteri Azotobacter Dan Hijauan Mucuna Bracteata Dalam Meningkatkan Hara Nitrogen Kompos Tandan Kosong Kelapa Sawit, Jurnal Agroekoteknologi, Vol.1 No.1.

Hendra, D dan Winarni I, 2003, Sifat Fisis Dan Kimia Briket Arang Campuran Limbah Kayu Gergajian Dan Sabetan Kayu, Buletin penelitian hasil hutan, Vol.21 No.3.

Isroi, 2008, Cara Mudah Mengomposkan Tandan Kosong Kelapa Sawit, https://isroi.com/2008/02/25/cara-mudah-mengomposkan-tandan-kosong-kelapa sawit.

Pecawan, Y, 2015, Minim Subsidi, Petani Muko-muko Kekurangan Pupuk 10 Ribu Ton Per Tahun, Antara News. 